\title{
Perfil da fluência da fala na síndrome de Williams-Beuren: estudo preliminar $* * * * *$
}

\author{
Speech fluency profile in Williams-Beuren syndrome: a preliminary \\ study
}

\begin{abstract}
Natalia Freitas Rossi*
Deise Helena de Souza**

Danilo Moretti-Ferreira***

Célia Maria Giacheti****
\end{abstract}

*Fonoaudióloga. Doutoranda em Ciências Biológicas (Genética) do Departamento de Genética do Instituto de Biociências de Botucatu (IBB Unesp) - São Paulo. Endereço para correspondência: Rua Jundiaí, 1215 Matão - São Paulo - CEP 15990-510 (nfrossi@hotmail.com).

**Biomédica. Doutoranda em Ciências Biológicas (Genética) do Departamento de Genética - IBB - Unesp - São Paulo. Citogeneticista do Departamento de Genética - IBB - Unesp - São Paulo.

***Biomédico. Professor LivreDocente do Departamento de Genética IBB - Unesp - São Paulo.

****Fonoaudióloga. Professora LivreDocente do Departamento de Fonoaudiologia da Faculdade de Filosofia e Ciências de Marília (FFC Unesp).

*****Trabalho Realizado no Departamento de Genética do IBB Unesp com apoio do Conselho Nacional de Desenvolvimento Científico e Tecnológico - CNPq.

Artigo Original de Pesquisa

Artigo Submetido a Avaliação por Pares

Conflito de Interesse: não

Recebido em 09.09.2008. Revisado em 31.01.2009. Aceito para Publicação em 04.05.2009.

\begin{abstract}
Background: the speech fluency pattern attributed to individuals with Williams-Beuren syndrome (WBS) is supported by the effectiveness of the phonological loop. Some studies have reported the occurrence of speech disruptions caused by lexical and semantic deficits. However, the type and frequency of such speech disruptions has not been well elucidated. Aim: to determine the speech fluency profile of individuals with WBS and to compare the speech performance of these individuals to a control group matched by gender and mental age. Method: Twelve subjects with Williams-Beuren syndrome, chronologically aged between 6.6 and 23.6 years and mental age ranging from 4.8 to 14.3 years, were evaluated. They were compared with another group consisting of 12 subjects with similar mental age and with no speech or learning difficulties. Speech fluency parameters were assessed according to the ABFW Language Test: type and frequency of speech disruptions and speech rate. The obtained results were compared between the groups. Results: In comparison with individuals of similar mental age and typical speech and language development, the group with Williams-Beuren syndrome showed a greater percentage of speech discontinuity, and an increased frequency of common hesitations and word repetition. Conclusion: The speech fluency profile presented by individuals with WBS in this study suggests that the presence of disfluencies can be caused by deficits in the lexical, semantic, and syntactic processing of verbal information. The authors stress that further systematic investigations on the subject are warranted.
\end{abstract} Key Words: Williams-Beuren Syndrome; Speech Production Measurement; Language.

\section{Resumo}

Tema: o padrão de fala fluente atribuído aos indivíduos com a síndrome de Williams-Beuren sustenta-se pela efetividade da alça fonológica. Alguns estudos citaram a ocorrência de disfluências decorrentes de prejuízos léxico-semânticos, entretanto, a quebra de fluência não foi bem especificada quanto ao tipo e freqüência de ocorrência. Objetivo: obter o perfil da fluência da fala de indivíduos com a SWB e comparar com um grupo controle pareado por gênero e idade mental semelhante. Método: foram avaliados 12 sujeitos com síndrome de Williams-Beuren a com idade cronológica entre 6,6 a 23,6 e idade mental de 4,8 a 14,3 anos que foram comparados a outros 12 sujeitos de idade mental semelhante com ausência de dificuldades de linguagem/aprendizagem. Para avaliação da fluência foi utilizado o Teste de Linguagem Infantil - ABFW, na área de fluência, que possibilitou classificar, quantificar e comparar os dois grupos quanto às tipologias e frequiência de rupturas e velocidade de fala. Resultados: o grupo com a síndrome de Williams-Beuren (SWB) apresentou maior porcentagem de descontinuidade de fala e freqüência aumentada para disfluências comuns do tipo hesitação e repetição de palavras quando comparados aos indivíduos com idade mental semelhante e com desenvolvimento típico de fala e linguagem. Conclusão: O perfil da fluência da fala apresentado pelos indivíduos com a SWB neste estudo mostrou a presença de disfluências que podem ser decorrentes de prejuízo no processamento léxico-semântico e sintático da informação verbal; ressaltando-se, pois a necessidade de investigações mais sistemáticas sobre este tema.

Palavras-Chave: Síndrome de Williams-Beuren; Medida da Produção da Fala; Linguagem. 


\section{Introduction}

Williams-Beuren syndrome (WBS) occurs in 1/ 20,000 live births and is caused by the microdeletion of 20-25 genes on chromosome 7q11.23 including the elastin gene (ELN)(1). WBS neurocognitive profile has been reported to involve a dissociation between cognitive and language skills with an extreme weakness in visuospatial construction contrasting with a clear strength in verbal and auditory memory tasks(1-3). However, such dissociation has not been observed by other investigators(4-8).

The fluent speech pattern attributed to WBS individuals is supported by the motor and phoneticphonological domain of verbal production, which has been frequently associated with the effective functioning of the working memory phonoarticulatory loop(9-11) and with the language syntactic component $(2-4,10)$.

Few studies report the occurrence of speech disfluencies or disruptions in WBS. In these studies, disfluencies, not classified by type, were assessed from oral narrative tasks and attributed to impairment in not only lexical-semantics $(4,12-13)$ but also in narrative structuring(14) .

The production of fluent speech is one of the most complex skills that may be acquired by humans (15) as it reflects linguistic maturity(16). Thus, individuals with WBS - a genetic condition that involves mental retardation and language alterations - are expected to show impaired speech fluency. The purpose of this study was to determine the speech fluency profile in WBS individuals as compared to a control group matched for gender and mental age.

\section{Methods}

This study was approved by the Research Ethics Committee of Botucatu Medical School-São Paulo State University/UNESP (no 1238-2003 and process no 25000.057294/2003-23), and written informed consent was obtained from all participants and/or their parents according to Health National Committee, CNS/196/96(17).

Twenty-four individuals were allocated into two groups, G1 and G2.

G1 consisted of 12 individuals with a diagnosis of Williams-Beuren syndrome (WBS) including 6 males and 6 females with chronological age ranging from 6.6 to 23.6 years and mental age between 4.8 and 14.3 years. WBS diagnosis was confirmed by clinical examination and cytogenetic-molecular analysis using Fluorescence in situ hybridization (FISH).

G2 was formed by screening 22 individuals with chronological age ranging from 4 to 16 years of age who were selected by their school teachers according to the following criteria: no complaints of language/learning difficulties and no previous history of speech therapy or treatment for learning disability. Pre-, peri-, and post-natal data were obtained from parents/guardians to rule out factors that could affect language/learning and cause speech abnormalities. Of the 22 individuals who underwent psychometric evaluation, 12 (6 males and 6 females) with mental age ranging from 4.8 to 14.3 years (mean of 8.4years) were selected to participate in this study as controls.

Mental age was determined by Wechsler scales WISC III (18)and WAIS(19). The use of mental age to compare the groups with and without the syndrome was adopted here as a methodological resource to control intellectual performance-related variables while assessing fluency.

All individuals were taped using a SONY CCDTRV11E, 8-mm video camera. Speech samples collected for analysis were focused on self-report narratives in which individuals narrated personal experiences(20). Fluency assessment was based on the criteria proposed in the Test of Language ChildFluency(16). The measurements provided by the instrument were obtained from a speech sample containing at least 200 expressed syllables. The following speech fluency aspects were analyzed:

. disfluency type, which corresponded to the number of times each type of disfluency occurred (common disfluencies such as hesitations, interjections, revisions, unfinished words, repetition of segments and phrases; and stuttering disfluencies such as two or more repetitions of sounds and/or prolongations, blocking, pauses and intrusion). speech rate, measured in words per minute.

. frequency of speech disruptions (percentage of speech discontinuity out of the total number of common and stuttering disruptions) and percentage of stuttering disfluencies (stuttering disfluency rate).

For the statistical analysis of the results, the non-parametric test of Mann-Whitney(21) was used to compare performance between groups. Results are expressed as the minimum and maximum number value as well as the median value of each characteristic assessed in the group. Median values (Md) were used because excessively high or low 
measurements were obtained in G1, indicating an asymmetry in the distribution of frequencies. Significance level was set at $5 \%$ or $\mathrm{p}=0.05$. In order to highlight significant differences, the $(*)$ sign was used when $\mathrm{p}>0.01$ or $\mathrm{p}<0.05$, and $(* *)$ for $\mathrm{p}<0.01)$.

\section{Results}

Determining speech fluency profile in WBS individuals and comparing them with normal controls of similar mental age allowed the identification of statistical differences in performance between the groups studied (Table 1).

Table 1 shows that the frequencies of common and stuttering disfluencies differed between groups indicating a higher frequency distribution in G1 than in $\mathrm{G} 2$.

The analysis of stuttering disfluencies revealed an asymmetric frequency distribution resulting from the excessively high measurements of stuttering disruptions obtained among G1 individuals.

The Mann-Whitney test showed no significant difference in speech rate median values which were within the normal range in both groups.

Table 2 illustrates the comparative analysis of G1 and $\mathrm{G} 2$ regarding speech disruption percentage. It is noteworthy that the asymmetry in the distribution of frequencies caused by the excessively high disruption measurements obtained in G1, favored the occurrence of a statistically significant difference between groups.

TABLE 1. Comparison of the median values of common and stuttering disruptions in G1 and G2.

\begin{tabular}{|c|c|c|c|c|c|c|c|c|}
\hline \multirow{2}{*}{ Type } & \multicolumn{3}{|c|}{ G1 } & \multicolumn{3}{|c|}{ G2 } & \multirow{2}{*}{\multicolumn{2}{|c|}{ p-value }} \\
\hline & Minimum & Maximum & Median & Minimum & Maximum & Median & & \\
\hline \multicolumn{9}{|l|}{ commom disfluency } \\
\hline hesitation & 0.0 & 6.0 & 2.5 & 0.0 & 5.0 & 1.5 & 0.043 & $*$ \\
\hline interjection & 0.0 & 20.0 & 2.0 & 0.0 & 13.0 & 4.5 & 0.603 & \\
\hline revision & 0.0 & 2.0 & 0.0 & 0.0 & 1.0 & 0.0 & 0.149 & \\
\hline unfinished word & 0.0 & 5.0 & 0.0 & 0.0 & 1.0 & 0.0 & 0.133 & \\
\hline word repetition & 0.0 & 15.0 & 2.0 & 0.0 & 3.0 & 0.0 & 0.010 & $*$ \\
\hline repetition of segments & 0.0 & 5.0 & 0.0 & 0.0 & 2.0 & 0.0 & 0.470 & \\
\hline repetition of phrases & 0.0 & 2.0 & 0.0 & 0.0 & 1.0 & 0.0 & 0.686 & \\
\hline \multicolumn{9}{|l|}{ stuttering disfluency } \\
\hline syllable repetition & 0.0 & 2.0 & 1.0 & 0.0 & 0.0 & 0.0 & 0.015 & $*$ \\
\hline sound repetition & 0.0 & 3.0 & 0.0 & 0.0 & 0.0 & 0.0 & 0.729 & \\
\hline prolonging & 0.0 & 12.0 & 0.0 & 0.0 & 0.0 & 0.0 & 0.166 & \\
\hline Blocking & 0.0 & 2.0 & 0.0 & 0.0 & 0.0 & 0.0 & 0.488 & \\
\hline pause (over 2 seconds) & 0.0 & 4.0 & 0.0 & 0.0 & 0.0 & 0.0 & 0.299 & \\
\hline intrusion of sounds or segments & 0.0 & 3.0 & 0.0 & 0.0 & 0.0 & 0.0 & 0.488 & \\
\hline
\end{tabular}

Test of Mann Whitney $\quad * \mathrm{p}<0.05 \quad * * \mathrm{p}<0.01$

TABLE 2. Comparative analysis of disruption frequencies between groups.

\begin{tabular}{|c|c|c|c|c|c|c|c|c|}
\hline \multirow{2}{*}{ Speech disruptions } & \multicolumn{3}{|c|}{ G1 } & \multicolumn{3}{|c|}{ G2 } & \multirow{2}{*}{ p-value } & \\
\hline & Minimum & Maximum & Median & Mínimo & Maximum & Median & & \\
\hline percentage of speech discontinuity* & 1.0 & 30.0 & 78 & 1.0 & 9.0 & 2.8 & 0.019 & $*$ \\
\hline percentage of stuttering discontinuity** & 0.0 & 8.0 & 15 & 0.0 & 0.0 & 0.0 & 0.002 & $* *$ \\
\hline
\end{tabular}

Test of Mann Whitney $\quad * \mathrm{p}<0.05 \quad * * \mathrm{p}<0.01$ 


\section{Discussion}

This study shows that WBS speech fluency profile differed from that observed in controls regarding the frequency of speech disruptions, including common and stuttering disfluencies (Table 1). This caused an increase in the frequency of speech discontinuity in the WBS group in comparison with the control group (Table 2).

Overall, the careful analysis of fluency profile in the group of individuals affected by WBS corroborated the findings reported in the various studies cited in the introduction of this article. In this study, stuttering disfluencies were not frequent in WBS individuals, supporting the assumption that speech is fluent as phono-articulatory and motor speech components are preserved(9-11). Secondly, the analysis of the data collected points to lexicalsemantic $(4,12-13)$ and syntactic failures among WBS individuals. In contrast with other reports(2-4), the WBS group frequently showed impaired verbal production in terms of utterance structure and content, such as truncated and incomplete utterances.

These findings demonstrate that linguistic and fluency aspects vary even between groups of similar mental age. This variation may be explained by the mental retardation factor, which is characteristic in WBS and causes a delay in the maturation of fluency neurolinguistic system. As demonstrated in a study of Brazilian Portuguese speakers, fluency tends toward being functional as early as the first years of life (22).

Our results suggest that the higher frequency of hesitations and word repetitions observed in the speech of WBS individuals may represent linguistic strategies to cope with difficulties in word recall that result in speech disruptions.

Hesitations behave differently in comparison with the repetition of words and segments because they do not cause syntagmatic disruptions providing the extra time necessary for the temporal adjustment of the paradigmatic and syntagmatic axis(23).

In general, studies of the relationship between grammar and disfluencies are still rarely available in the literature(24), especially in the WBS population. The syntactic difficulties presented by WBS individuals suggested a correlation with the level of cognitive deficit. These alterations occurred in more complex domains $(2,25)$ in the cases of borderline or mild mental retardation, whereas cases of moderate mental retardation showed quantitative and qualitative restrictions in the construction of spoken text which transcend specifically syntactic issues.
It is worth of note, however, that the findings reported here are preliminary and should be analyzed in-depth in a study specifically designed for this purpose.

The level of cognitive impairment may explain the difficulty in conducting studies of fluency in populations affected by genetic syndromes as mental retardation is part of their phenotype. Severe intellectual impairment makes difficult to obtain speech samples fit for the analysis of fluency-specific aspects(26). Studies of fluency in individuals with genetic syndromes are still scarcer than those focusing communication disorders. The absence of disfluencies, that typically characterizes stuttering, may be one of the factors contributing for such scarcity placing non-stuttering disfluencies in a marginal position in relation to fluency disorders in individuals affected by genetic syndromes.

The method used in this study allowed the collection of important information on disfluency frequency and types in WBS. To our knowledge, no studies using similar methods are reported in the literature.

Our findings allow us to look at speech fluency in WBS under a different light by analyzing its associations with neuromotor and linguistic aspects inherent to speech fluency that have not been appraised in other local or international researches of this syndrome. Moreover, the study method can be used nationwide and may as well as be employed to assess individuals with other genetic conditions involving mental retardation or unspecific mental deficiencies for comparison.

\section{Conclusion}

This study demonstrated that an instrument designed to assess speech fluency in individuals with WBS is sensitive enough to detect linguistic impairment based on the speech fluency profile seen in this syndrome. This instrument also allowed a further analysis of the characteristics and frequency of disfluencies suggestive of a correlation with lexical impairment. Other studies have already pointed out the presence of disfluencies as part of the lexical difficulties observed in WBS. However, they did not include the analysis of fluency considering the type and frequency of speech disruptions.

Since the results reported here are preliminary, further studies of the profile of speech fluency in WBS are necessary and should include a larger sample, an in-depth analysis of linguist aspects and comparison with the speech fluency profile seen in 
other genetic conditions involving mental retardation, such as Down syndrome, and other unspecific mental deficiencies. This would greatly contribute for the establishment of more consistent correlations between dissociations among fluencyrelated linguistic deficits and mental retardation.

\section{References}

1. Mervis CB, Becerra AM. Language and communicative development in Williams syndrome. Ment Retard Dev Disabil Res Rev. 2007;13(1):3-15.

2. Mervis CB, Robinson, Bertrand J, Morris CA, KleinTasman BP, Armstrong SC. The Williams syndrome cognitive profile. Brain Cogn. 2000;44(3):604-28.

3. Jarrold C, Baddeley AD, Hewes AK, Phillips C. A longitudinal assessment of diverging verbal and non-verbal abilities in the Williams syndrome phenotype. Cortex. 2001;37(3):423-31.

4. Bellugi U, Lichtenberger L, Jones W, Lai ZST, George MI. I. The neurocognitive profile of Williams syndrome: a complex pattern of strengths and weaknesses. J Cogn Neurosci. 2000;(12 Suppl 1):7-29.

5. Gonçalvez OF, Pérez A, Henriques M, Prieto M, Lima MR, Siebert MF, Nuno S. Funcionamento cognitivo e produção narrativa na síndrome de Williams: congruência ou dissociação neurocognitiva? Int J Clin Health Psychol. 2004;4(3):623-38.

6. Carrasco X, Castilho S, Avarena T, Rothhammner P. Williams syndrome: pediatric, neurologic and cognitive development. Pediatr Neurol. 2005;32(3):166-72.

7. Porter MA, Coltheart M. Cognitive heterogeneity in Williams syndrome. Dev. Neuropsychol. 2005;27(2):275306 .

8. Rossi NF, Moretti-Ferreira D. Giacheti CM. Perfil comunicativo de indivíduos com a síndrome de WilliamsBeuren. Rev Soc Bras Fonoaudiol. 2007;12(1):1-9.

9. Vicari S, Bellucci S, Carlesimo GA. Procedural learning deficit in children with Williams syndrome. Neuropsychologia. 2001;39(7):665-77.

10. Volterra V, Caselli MC, Capirci O, Tonucci F, Vicari S. Early linguistic abilities of italian children with Williams syndrome. Dev Neuropsychol. 2003;23(1-2):33-58.

11. Somerville MJ, Mervis CB, Young EJ, Seo EJ, Del Campo M, Bamforth S, et al. Severe expressive-language delay related to duplication of the Williams-Beuren locus. N Engl J Med. 2005;353(16):1694-701.

12. Kamirloff-Smith A, Brown JH, Grice S, Paterson S. Dethroning the myth: cognitive dissociations and innate modularity in Williams syndrome. Dev Neuropsychol. 2003;23(1-2):227-42.

13. Reilly J, Losh M, Bellugi U, Wulfeck B. "Frog, where are you?" Narratives in children with specific language impairment, early focal brain injury and Williams syndrome. Brain Lang. 2004;88(2):229-47.
14. Garayzábal HE, Prieto MF, Sampaio A, Gonçalves O. Cross-linguistic assessment of verbal production from a narrative task in Williams syndrome. Psicothema. 2007;19(3):428-34.

15. Nickels L. Spoken word production. In: Raap B. The handbook of cognitive neuropsychology: what deficits reveal about the human mind. New York: Psychology Press; 2001. p. 291-320.

16. Andrade CRF. Fluência. In: Andrade CRF, Beffi-Lopes DM, Fernandes FDM, Wertzner HF. ABFW: Teste de Linguagem Infantil nas Áreas de Fonologia, Vocabulário, Fluência e Pragmática. $2^{\mathrm{a}}$ ed. rev. ampl. atual. Barueri: PróFono; 2004. p. 51-82.

17. Brasil. Ministério da Saúde. Conselho Nacional de Saúde. Resolução 196/96: diretrizes e normas regulamentadoras de pesquisas envolvendo seres humanos. Brasília: Conselho Nacional de Saúde; 2003. 20p.

18. Wechsler D. WISC-III: escala de inteligência Wechsler para crianças: manual. 3a. ed. São Paulo: Casa do Psicólogo; 2002. p. 322.

19. Wechsler D. WAIS-III: escala de inteligência Wechsler para adultos. São Paulo: Casa do Psicólogo; 2004. p. 271.

20. Hudson JA, Shapiro LR. From knowing to telling: the development of children's script, stories and personal narratives. In: McCabe A, Peterson C, editors. Developing narrative structure. New Jersey: Lawrence Erlbaum; 1991. p. $89-136$

21. Siegel S. Estatística não-paramétrica: para as ciências do comportamento. São Paulo: Mcgraw-Hill do Brasil, 1975.

22. Martins VO, Andrade CRF. Perfil evolutivo da fluência da fala de falantes do português brasileiro. Pró-Fono. 2008;20(1):7-12.

23. Juste F, Andrade CRF. Tipologia das rupturas de fala e classes gramaticais em crianças gagas e fluentes. Pró-Fono. 2006;18(2):129-40

24. Merlo S. Hesitações na fala semi-espontânea: análise por séries temporais [dissertação]. Campinas: Instituto de Estudos da Linguagem, Universidade Estadual de Campinas, 2006.

25. Brock J. Language abilities in Williams syndrome: a critical review. Dev Psychopathol. 2007;19(1):97-127.

26. Van Borsel J, Tetnowski JA. Fluency disorders in genetic syndromes. J Fluency Disord. 2007; 32(4):279-96. 